\title{
The Life and Death of a Child: Mortuary and Bodily Manifestations of Coast-Interior Interactions during the Late Formative Period (AD 100-400), Northern Chile
}

\author{
Christina Torres-Rouff (D), Gonzalo Pimentel, William J. Pestle, Mariana Ugarte, \\ and Kelly J. Knudson
}

\begin{abstract}
Camelid pastoralism, agriculture, sedentism, surplus production, increasing cultural complexity, and interregional interaction during northern Chile's Late Formative period (AD 100-400) are seen in the flow of goods and people over expanses of desert. Consolidating evidence of material culture from these interactions with a bioarchaeological dimension allows us to provide details about individual lives and patterns in the Late Formative more generally. Here, we integrate a variety of skeletal, chemical, and archaeological data to explore the life and death of a small child (Calate-3N.7). By taking a multiscalar approach, we present a narrative that considers not only the varied materiality that accompanies this child but also what the child's life experience was and how this reflects and shapes our understanding of the Late Formative period in northern Chile. This evidence hints at the profound mobility of their youth. The complex mortuary context reflects numerous interactions and long-distance relationships. Ultimately, the evidence speaks to deep social relations between two coastal groups, the Atacameños and Tarapaqueños. Considering this suite of data, we can see a child whose life was spent moving through desert routes and perhaps also glimpse the construction of intercultural identity in the Formative period.
\end{abstract}

Keywords: bioarchaeology, life course, stable isotope analysis, radiogenic isotope analysis

El pastoreo de camélidos, la agricultura, el sedentarismo, la producción de excedentes, la creciente complejidad cultural y la interacción interregional durante el Período Formativo Tardío del norte de Chile (100-400 dC), se pueden observar y analizar a partir del flujo de bienes y personas que se movieron por el vasto Desierto de Atacama. Integramos datos bioantropológicos, químicos y arqueológicos para estudiar la vida y la muerte de un viajero infante (Calate-3N.7), con el objetivo de discutir cómo las redes de interacción de esta época se manifiestan en su cuerpo y en su contexto mortuorio. Utilizamos una perspectiva íntima y multi-escalar para reflexionar sobre la experiencia de vivir en dicha época. El caso de Calate-3N.7, corresponde al entierro de un individuo infantil (4-6 años) que falleció mientras participaba de un viaje grupal entre la costa Pacífica y el interior, a quien ofrendaron un complejo ajuar como parte del ritual mortuorio. Los dos valores de estroncio radiogénico obtenidos no calzan completamente con lo esperado para un individuo costero o alguien del interior. Los valores que corresponderían a un intermedio entre la costa y el interior sugieren la posibilidad de que pudo tratarse de un viajero habitual. Sus restos no mostraron evidencias de enfermedades infantiles, dificultades en su desarrollo u otros indicadores de malnutrición. Nuestras

Christina Torres-Rouff (ctorres-rouff@ucmerced.edu, corresponding author) — Department of Anthropology and Heritage Studies, University of California, Merced, 5200 N. Lake Road, Merced, CA 95343, USA; Instituto de Arqueología y Antropología, Universidad Católica del Norte, Calle Tebenquinche S/N, San Pedro de Atacama, Chile Gonzalo Pimentel ש Universidad de Tarapacá Arica-Sede Iquique, Av. Luis Emilio Recabarren 2477, Iquique, Tarapacá, Chile; Fundación Patrimonio Desierto de Atacama, Alarife Gamboa 80, Providencia, Santiago, Chile (gpimentel@desiertoatacama.com)

William J. Pestle $\square$ Department of Anthropology, University of Miami, PO Box 248106, Coral Gables, FL 33124, USA (w.pestle@miami.edu)

Mariana Ugarte - Fundación Patrimonio Desierto de Atacama, Alarife Gamboa 80, Providencia, Santiago, Chile (mugarte@desiertoatacama.com)

Kelly J. Knudson a Center for Bioarchaeological Research, School of Human Evolution and Social Change, 900 South Cady Mall, Arizona State University, Tempe, AZ 85287, USA (kelly.knudson@asu.edu)

Latin American Antiquity 33(1), 2022, pp. 187-204

Copyright (C) The Author(s), 2021. Published by Cambridge University Press on behalf of the Society for American Archaeology. This is an Open Access article, distributed under the terms of the Creative Commons Attribution licence (http://creativecommons.org/licenses/by/4.0/), which permits unrestricted re-use, distribution, and reproduction in any medium, provided the original work is properly cited.

doi:10.1017/laq.2021.56 
evidencias isotópicas de carbón y nitrógeno muestran una dieta variada, aunque predominantemente marina. El contexto mortuorio presentó un variado ajuar que evidencia una sostenida interacción y estrechos lazos entre la costa Pacífica y los oasis del interior, mientras que el hallazgo de un fragmento de pipa procedente del Complejo San Francisco (noroeste argentino) nos habla de una red de intercambio de mayor amplitud. Así, podemos ver que la microhistoria de este infante viajero, que transcurrió moviéndose a través de los senderos desérticos entre los nodos de la costa y los oasis del interior, nos permite contar con una mirada dentro de la movilidad y el intercambio durante el Período Formativo Tardío.

Palabras claves: bioarqueología, curso de vida, análisis de isótopos estables, análisis de isótopos radiogénicos

B roadly speaking, the Formative period in the Andes (1500 BC-AD 400) was a time of substantial change, with shifts in subsistence patterns accompanying an intensification of social complexity and technological advances (e.g., Lumbreras 2006). In northern Chile's Atacama Desert there is ample evidence of camelid pastoralism, agriculture, sedentism, surplus production, and increasing cultural complexity (Castro et al. 2016; Muñoz et al. 2016; Núñez et al. 2006; Uribe et al. 2020). This period, however, is notable for its diversity, with local populations responding at different rates and in varied ways to change. What began as systems of complementarity between different ecological levels ultimately consolidated into a complex and extensive multidirectional meshwork of relationships. In part, this has been understood as an Andeanization process promoted from the highlands via widespread cultural phenomena with close links to highland centers like Wankarani (e.g., Rivera 2002). This view contrasts with a perspective that emphasizes continuity with local Archaic period traditions (e.g., Muñoz et al. 2016; Núñez and Santoro 2011). Nevertheless, there is agreement that the longdistance caravan system created a mosaic of relationships among groups (Muñoz et al. 2016:184-186). By the Late Formative (Castro et al. 2016; Muñoz et al. 2016) there was significant interaction and exchange and some level of integration of people living in varied population centers across the arid expanse of the Atacama Desert. By consolidating evidence of material culture with a human dimension in this article, we are able to provide details about individual lives and open doors into a consideration of northern Chile's Late Formative period.

A life, and consequently a body, can reflect movement and exchanges and speak to communal trends. The details of each life are idiosyncratic but at the same time are formed in relation to society and the environment. Considering individuals through a social bioarchaeology approach (Agarwal and Glencross 2011) that incorporates life history and embodiment allows us to explore human experiences writ large through the subtleties of a particular life. In this article, we integrate a variety of skeletal, chemical, and archaeological data to explore the life and death of a small child, Calate-3N.7, who died between the ages of four and six and was buried in the open desert along a prehistoric trail during the Late Formative period in the Tarapacá region of Chile's Atacama Desert (Figure 1; Table 1). Calate served as a throughway for travelers in historic and prehistoric times, providing a rest area in this harsh landscape. Research over the past decade has revealed numerous campsites, offerings, and burials that reflect its character as a path connecting nodes on the coast to those in the interior oases (Figure 2; Gallardo 2017; Pimentel and Ugarte 2017; Pimentel et al. 2017). The individuals buried along these routes reflect the varied cultural groups engaged in trade and social interaction across the desert.

In archaeological terms, what we see when exploring the lives of travelers are the sum of their burdens - what materials they transport, where they come from, what symbols are exchanged, and how these objects reflect differential value. However, as Gallardo (2017:16) notes, these material remains provide evidence of transactions and do not necessarily define the quality of interactions. Here, we focus on the life of a traveler who crossed immense deserts at a young age. We argue that this view, which aims to provide the details of a life by showing how that life embodied movements and exchanges, can help bring to a human scale the patterns of social interaction that characterize a period.

\section{A Social Bioarchaeological Approach}

We frame this research with a life-history perspective couched in the framework of 


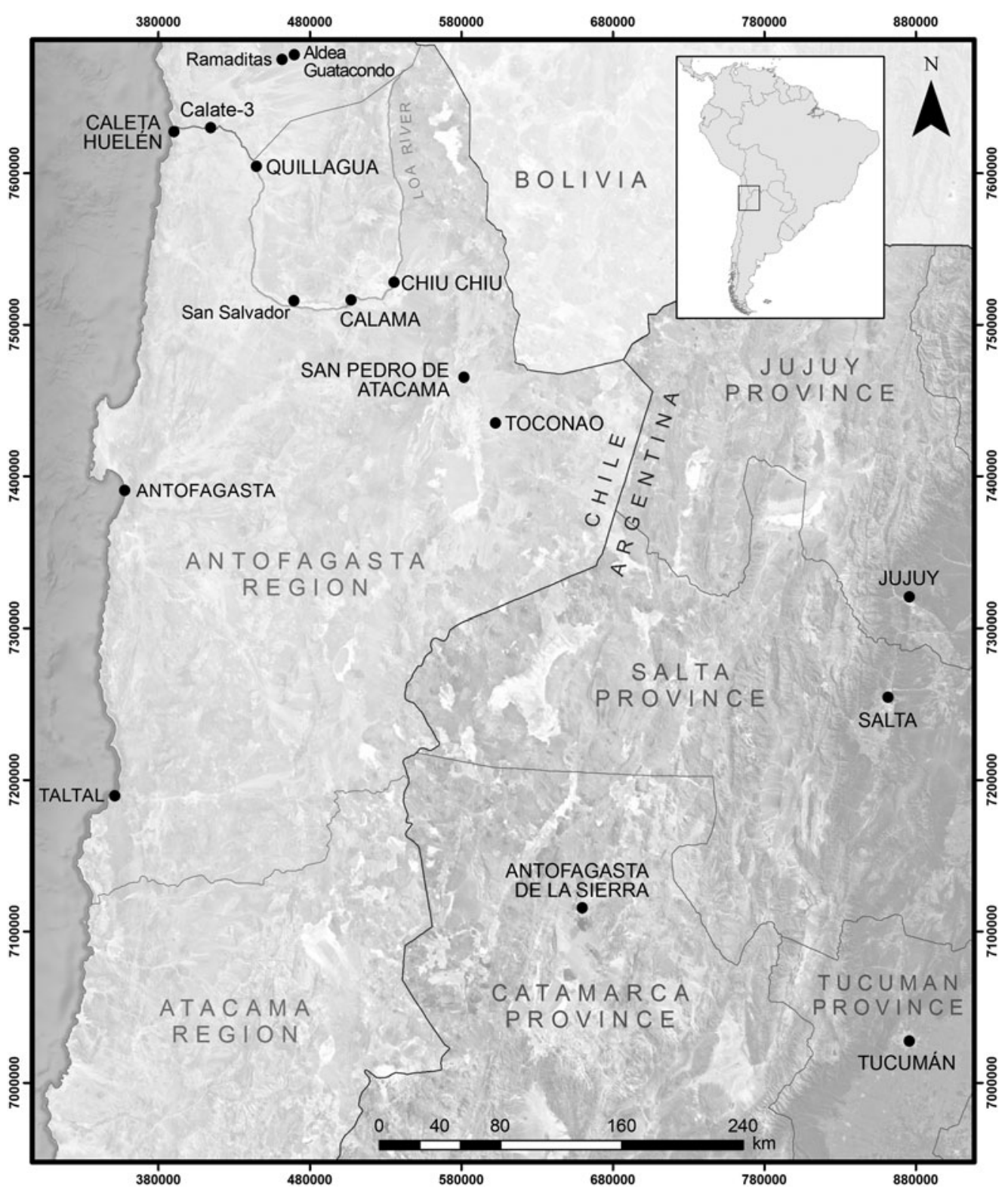

Figure 1. Map of the region.

embodiment. As Agarwal (2016:S130) writes, these approaches are focused on the "interrogation of human life as a result of interrelated and cumulative events over not only the timeframe of individuals, but also over generations at the community level." They allow for a multiscalar consideration that can give insight not only into individual experiences but also into how they reflect social contexts and social change (e.g., Torres-Rouff and Knudson 2017). This allows us to see the ways in which these interaction networks manifest in both the body and in death, as well as how the individual experience reflects life in this time.

Integrating this life-history approach into bioarchaeology directly with an embodiment perspective, we address the physical body as it engages with the social world. This is particularly 
Table 1. Radiocarbon Dates from Calate 3N.

\begin{tabular}{|c|c|c|c|c|}
\hline Sample ID & Lab Code & Material & Radiocarbon Age & Calibrated Radiocarbon Age \\
\hline CH3N E13 C2 R2 & Beta 275724 & carbon & $1950 \pm 40 \mathrm{BP}$ & $\begin{array}{c}40-20 \mathrm{cal} \text { BC }[p=0.04] \\
\text { cal AD 20-210 }[p=0.96]\end{array}$ \\
\hline CH3N E15 C1 R3 & AA98012 & carbon & $1597 \pm 36 \mathrm{BP}$ & cal AD $420-590[p=1.0]$ \\
\hline CH3N E14 C1 R1 & AA98002 & carbon & $1581 \pm 36 \mathrm{BP}$ & $\begin{array}{l}\text { cal AD 420-600 [p }=0.995] \\
\text { cal AD 620-630[p=0.005] }\end{array}$ \\
\hline $\mathrm{CH} 3 \mathrm{~N}$ E7 & AA90201 & textile & $1805 \pm 38 \mathrm{BP}$ & $\begin{array}{l}\text { cal AD } 140-160[p=0.023] \\
\text { cal AD } 160-180[p=0.023] \\
\text { cal AD 200-370 }[p=0.955]\end{array}$ \\
\hline
\end{tabular}

Notes: All dates (Pimentel et al. 2017:37, 47) were calibrated using Calib 8.2 (Stuiver et al. 2020) and the SHCal20 calibration curve (Hogg et al. 2020). For lab codes, "Beta" designates dates generated by Beta Analytic, and "AA" designates dates generated by the University of Arizona Accelerator Mass Spectrometry Laboratory. Dates older than 1000 BP are rounded to the nearest decade (Stuiver and Polach 1977). Calibrated radiocarbon ages at 2-sigma.

salient in the consideration of childhood-a term plagued by the conflation of social and biological perceptions (Beauchesne and Agarwal 2018; Cavagnoud et al. 2013). It is worth noting that in precolumbian northern Chile, infants and children were frequently buried, often with elaborate mortuary treatment, in the same ascribed mortuary spaces in which adults were interred (e.g., González-Ramírez et al. 2019; Torres-Rouff and Knudson 2017; Uribe et al. 2015). Childhood, importantly, must be conceived not only as socially constructed but also as a stage of life with myriad expressions. This "plurality of childhoods" applies not only between cultural groups but also to the workings of each one, considering intersections with age, sex, class, and other aspects of identity (Cavagnoud et al. 2013:325). Although we cannot speak to specific concepts of childhood among particular populations, the individual considered here was clearly in one of the earlier parts of life, coming out of a period of full dependence to engage with the world around them.

As Meskell (2000:13) notes, the embodied experience represents the "interplay of natural, social, cultural and psychical phenomena." As such, we can glimpse more than a static snapshot of death, allowing us to explore the ways that the body developed over time, even during brief periods, and interacted with the world around it. It should be noted that individuals will have complex and likely overlapping identities reflected in their bodies that can be glimpsed archaeologically at certain moments in the life course. The integration of the osteological data of a life with contextual sociohistorical information derived from the mortuary space can shed light on the production of identity and the multiple intersections of exchange, mobility, and personhood.

In this article, we use this fine-grained perspective to explore the experiences and environments of interaction that surround the life and death of a child and thus the social character of these movements. These important relationships are reflected in mortuary spaces and the people who are buried during moments of mobility. By taking a multiscalar approach, we present a narrative that considers not only the varied materiality that accompanies this child but also what the life experience was, and how it reflects and shapes our understanding of the Late Formative period in northern Chile.

\section{Background and Context}

In Tarapacá, the Late Formative (AD 100-900) witnessed the consolidation of sedentism, continued rise of complexity and production of resource excess, and the growth of interregional trade networks involving coastal and interior peoples (Muñoz et al. 2016). Throughout the Atacama, most habitable areas of the desert became occupied at this time, with different subsistence strategies, varied food resources, and technological innovations leading to the aggregation of population into larger settlements and shifts toward social integration that helped minimize risk in both the interior oases and along Chile's coastline (Castro et al. 2016:242; Gallardo 2017; Pestle et al. 2015; Ugalde et al. 2021). By this time, the populations of the Valles Occidentales 


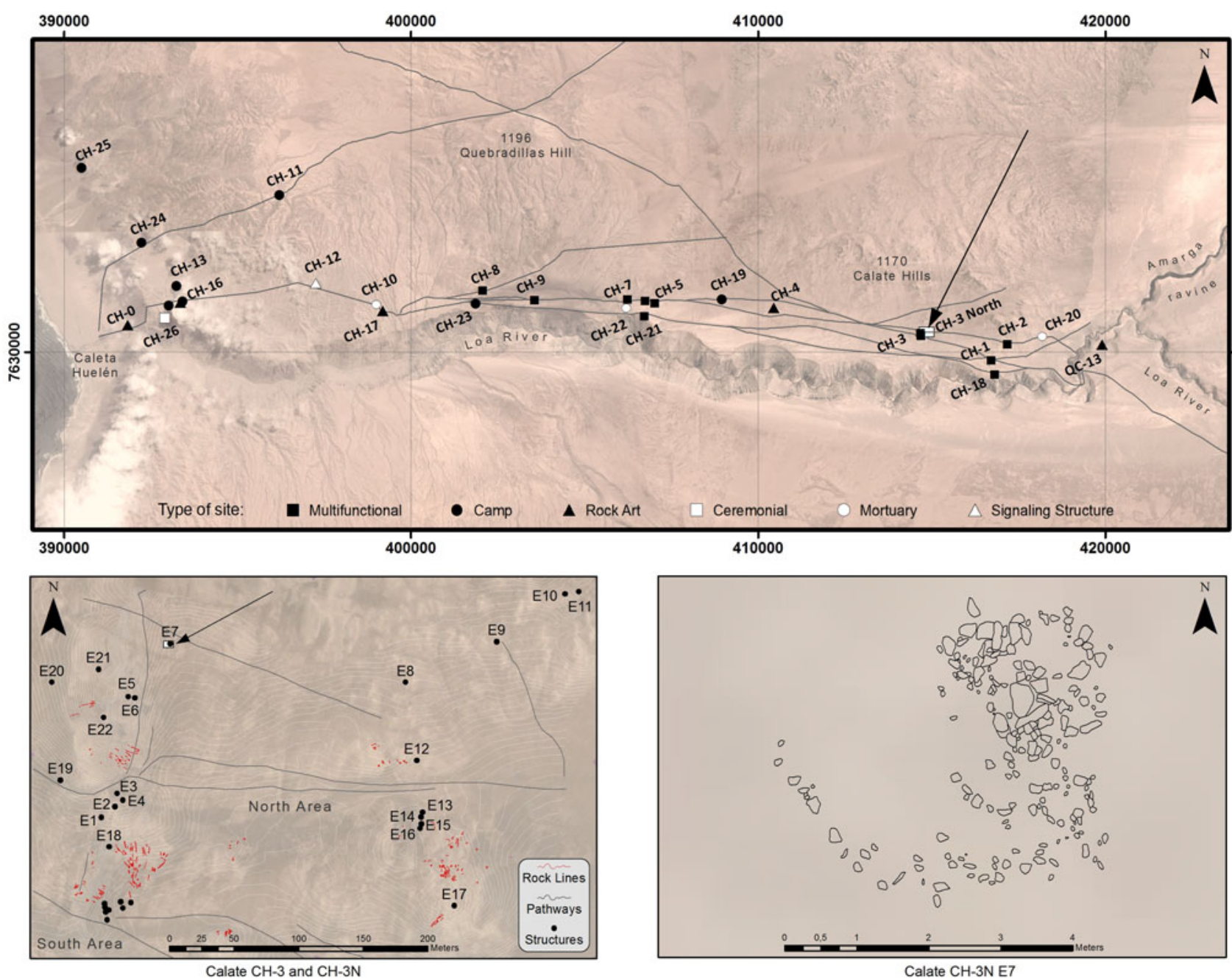

Figure 2. Top, Detailed map of Calate indicating location of Calate 3; bottom left, map of the site of Calate 3 and Calate $3 \mathrm{~N}$ indicating burial location; and bottom right, drawing of the burial of individual $3 \mathrm{~N} .7$ before excavation. (Color online) 
are fully sedentary-maintaining complementarity between agricultural, pastoral, and hunting and gathering resources - interregional exchange networks have been expanded and consolidated, and the differences that define the "cultural regions" of Arica, Tarapacá, and Atacama begin to be seen (Adán et al. 2013; Castro et al. 2016; García et al. 2014; Muñoz et al. 2016; Uribe et al. 2020). During this time, the growth in complex interregional interaction networks is reflected in the flow of goods and people from the coast to interior to highlands and back again over large expanses of the desert (e.g., Cases et al. 2008; Pimentel et al. 2011).

The social complexity that characterizes the period reflects an incredible diversity in social organization and cultural patterns, with, for example, the early development of agriculture, evidence of significant interaction and information flow, the construction of elaborate space for rituals and communal gatherings at sites, and the complexity of associated cemeteries and material culture (Adán et al. 2007, 2013; Agüero and Cases 2004; Uribe 2006). Although certain elements, such as ceramics and textiles (Agüero 2012; Uribe and Vidal 2015), were shared across the region, there is evidence demonstrating that different localities had local autonomy in managing connections and interactions. Interactions at this time included contacts and exchanges across different ecological zones, as well as internal movement along the coast and within the valleys and oases. Together these result in a regional scale of interaction that extended beyond solely highland influences (e.g., Núñez and Dillehay 1979).

Calate is located about $25 \mathrm{~km}$ from the Pacific coast and $40 \mathrm{~km}$ from the Quillagua valley and oasis in a transition zone between the Cordillera de la Costa and the Pampa del Tamarugal, at about $700 \mathrm{~m}$ asl (Figure 1). The Calate sites are found in the Valles Occidentales subarea and demonstrate interactions that extend into the neighboring Circumpuneña and Altiplano Meridional subareas (Aldunate and Castro 1981). Calate functioned as a "funnel road" through which travelers going between Quillagua and Caleta Huelén-inland and costal nodes, respectively - were able to cross the Loa River. The sites reveal a long history of use, with materials suggesting that groups traversed this space as early as the Middle Archaic period (ca. $5000 \mathrm{BC}$ ) and that it was used regularly in the intervening centuries (Pimentel et al. 2017). The use of these routes to move foods and animals across the desert persisted into the historic period, and Calate continued to be a resting place (Odone 2017; Pimentel et al. 2017). The oases and other habitable areas of the interior were occupied by the Early Formative, suggesting the importance of the multicultural internodal spaces of Calate for connecting different population centers (e.g., Gallardo 2017). As such, routes and the bodies buried along the way bear evidence of these long-distance exchanges.

A pedestrian survey allowed us to record trails on the northern plateau of the Loa River originating from Tarapacá, the interior Atacama Desert, and the Pacific coast. Twenty-eight sites were registered with a total of 192 structures; of these, 13 were funerary (Figure 1; Pimentel et al. 2017). The individuals interred at Calate do not form a cohesive burial population: instead, they encompass a broad range of cultural practices and time periods from the Archaic through the colonial, with each burial appearing to be the product of individual circumstances, leading to the dispersed interment of these individuals. The nine burials recovered and studied thus far cover millennia of human occupation and range from expedient burials to the elaborate burial context we see at $3 \mathrm{~N} .7$ (Torres-Rouff et al. 2012). These burials include one other non-adult: an infant younger than six months old was buried at $\mathrm{CH} 9.1$ dating to the Late period (post-AD 1400). This infant was interred in a small pit with a small array of grave goods (fragments of black monochrome ceramic, pieces of net, sticks, textile and cord fragments, fish remains, maize cobs, and algarrobo pods), and the burial was covered with large rocks.

Calate 3, which comprises two sectors $(\mathrm{CH} 3$ and $\mathrm{CH} 3 \mathrm{~N}$ ), is multifunctional in nature (Figure 2). It is thought to have been in use during the Formative, with evidence suggesting ongoing usage through the end of the colonial period. A number of lineas de piedra (lines of stone), where multiple linear arrangements of stone were placed along the desert plains, were 
documented at the site. $\mathrm{CH} 3$ includes structures with dates showing use during the Late Formative period (ca. AD 420-600; Pimentel et al. 2017:37) and a burial (CH3.8) with dates from the late colonial period (post-AD 1500; Pimentel et al. 2017:44). CH3N, which also dates to the Late Formative, shows evidence of habitation structures, funerary components, and a series of assemblages deemed ceremonial in nature. We focus here on Calate-3N.7, which corresponds to the burial of a child accompanied by a suite of mortuary goods during the Late Formative period.

\section{Problem and Approach}

We explore this individual and the ways in which the child's life and death reflect the social context by integrating skeletal, biogeochemical, and archaeological data to investigate the patterns of social interaction seen in their body and grave. We discuss this data over the life course of individual $3 \mathrm{~N} .7$; these varied times provide us with different moments and aspects of the embodied lived experience. First, we consider radiogenic strontium isotope data to explore possible places of origin and consider practices of infant care through the modification of skull shape. We explore skeletal evidence of stress and health indicators that could result from this brief life. We move on to analyze stable carbon and nitrogen isotopes to document patterns of consumption during childhood. Finally, we consider the moment of burial in terms of the tomb, body, and myriad grave goods, thereby complementing our understanding of social relationships in life and death.

\section{Methods}

Calate-3N.7 was excavated and analyses conducted as part of FONDECYT 1090762, which was directed by Pimentel in 2009. The child was interred in a small pit burial in a difficult caliche and sand-laden environment at a depth of $82 \mathrm{~cm}$ with an $80 \times 40 \mathrm{~cm}$ extension. The individual was placed on their side in a flexed position within a thick textile wrapping accompanied by varied goods. Human remains and the material culture were later cleaned and analyzed in a laboratory setting. Radiocarbon dates were derived from a textile in the grave, in addition to carbonized remains from other structures at Calate $3 \mathrm{~N}$.

\section{Skeletal Analyses}

Human remains were examined macroscopically following standard bioarchaeological protocols after conducting a complete skeletal inventory (e.g., Buikstra and Ubelaker 1994). Although most of the remains were skeletonized and therefore available for analysis, some were still covered with soft tissue - primarily portions of the face, sternum and anterior ribs, and hands/feet - and therefore excluded from skeletal analyses as appropriate. Dental development was used to ascertain age. Given the very young age at death, no skeletal indicators were used to determine sex. We analyzed several standard bioarchaeological indicators of stress (linear enamel hypoplasia [LEH], cranial porosities, osteoperiostitis), evidence of dietary patterns (dental caries, antemortem tooth loss), and traumatic injury.

All indicators were observed macroscopically with 10x magnification. Observations for LEH, frequently associated with acute moments of stress during development, were made on the anterior dentition. Similarly, observations for cranial porosities that could suggest nutritional deficiencies (Walker et al. 2009) were made on the orbits and cranial vault. The specific etiology of skeletal lesions like cribra orbitalia is not completely understood, and as such they are frequently used as indicators of nonspecific stress, particularly in childhood (e.g., Lewis 2014). Finally, all long bones were observed for evidence of osteoperiostitis. Dentition was examined for evidence of dietary patterns and dental health via documentation of caries and antemortem tooth loss (AMTL), which frequently results from severe carious lesions (Hillson 1996). Although several factors influence the prevalence of dental caries, they are frequently used as an indicator of carbohydrate consumption (Hillson 1996; Marklein et al. 2019).

Observations were made for evidence of acute trauma in the form of depressions on the vault, linear fractures, facial fractures, and weapon wounds (e.g., Lovell 1997). This evidence included both peri- and antemortem injuries 
considered representative of interpersonal violence or accidental injury. All paleopathological changes were documented on the skeletal remains based on their presence and absence and scored following standard protocols.

Finally, cranial vault modification, a global practice with significant regional variation, was documented. This practice has a long and varied history in the Andes, where it is frequently imbued with elements of group identity. Here, we considered its presence, type, angle of pressure, degree, and symmetry of modification following protocols developed earlier (TorresRouff 2008).

\section{Radiogenic Strontium Isotope Analyses}

Radiogenic strontium isotope data $\left({ }^{87} \mathrm{Sr} /{ }^{86} \mathrm{Sr}\right)$ are used to examine paleomobility in archaeological human remains (see discussions in Bentley 2006; Knudson et al. 2010; Lewis et al. 2017; Slovak and Paytan 2011). Bioavailable strontium is incorporated into human dental and skeletal elements during formation, where it substitutes for calcium in tooth enamel and bone hydroxyapatite. When "local" strontium is imbibed or consumed, the ${ }^{87} \mathrm{Sr} /{ }^{86} \mathrm{Sr}$ values reflect the geologic region or regions in which that individual lived during enamel and bone formation. In the Archaeological Chemistry Laboratory at Arizona State University (ASU), samples were photographed, cast, and then mechanically cleaned by abrasion with a Dremel 3956-02 Variable Speed MultiPro drill equipped with an engraving cutter; we used it to remove adherent organic matter or contaminants, as well as the outermost layers, which are most susceptible to diagenetic contamination. Soil samples were partially dissolved to identify bioavailable strontium. Samples were analyzed for elemental concentrations on the quadrupole inductively coupled plasma mass spectrometer (Q-ICP-MS) in ASU's Metals, Environmental, and Terrestrial Analytical Laboratory (METAL); these data were used to infer diagenetic contamination. Strontium was then separated from the sample matrix using EiChrom SrSpec resin, and samples were analyzed using the METAL Neptune multi-collector inductively coupled plasma mass spectrometer (MC-ICP-MS). Recent ${ }^{87} \mathrm{Sr} /{ }^{86} \mathrm{Sr}$ analyses of strontium carbonate standard SRM-987 yield a value of ${ }^{87} \mathrm{Sr} /{ }^{86} \mathrm{Sr}=0.710261 \pm 0.000020(2 \sigma)$, which is in agreement with analyses of SRM-987 using a thermal ionization mass spectrometer (TIMS), where ${ }^{87} \mathrm{Sr} /{ }^{86} \mathrm{Sr}=0.710263 \pm$ $0.000016(2 \sigma)$ (Stein et al. 1997), and with analyses of SRM-987 using an identical MC-ICPMS, where ${ }^{87} \mathrm{Sr} /{ }^{86} \mathrm{Sr}=0.710251 \pm 0.000006(2 \sigma$; Balcaen et al. 2005).

\section{Stable Carbon and Nitrogen Isotope Analyses}

Extractions of target biomolecules (collagen and hydroxyapatite) were performed in the Stable Isotope Laboratory at the University of Illinois, Chicago. Collagen extraction followed a modified version of that established by Longin (1971) and detailed elsewhere (Pestle et al. 2016, 2017). Extraction and purification of bone hydroxyapatite followed the protocols of Lee-Thorp (1989) and Krueger (1991), with minor modifications (Pestle 2010). Collagen and hydroxyapatite isotopic analyses were performed at the Colorado Plateau Stable Isotope Laboratory following Pestle and colleagues (2015). Modeling of isotopic data was accomplished using the Bayesian FRUITS model of Fernandes and colleagues (2014), one of several such models developed with the goal of better bounding estimates of food source contribution. These approaches "offer a powerful means to interpret data because they can incorporate prior information, integrate across sources of uncertainty and explicitly compare the strength of support for competing models or parameter values" (Moore and Semmens 2008:471). All model parameters employed for 3N.7 follow those detailed in Pinder and colleagues (2019).

\section{Origins and Infancy}

To explore the earliest stage of life, we focus on radiogenic strontium analyses, which provide us with a means of identifying geographic origins; we follow this with documentation of the childrearing practice of cranial modification, which must be performed in infancy and creates a permanent alteration to head shape.

Because bone remodels throughout an individual's lifetime, bone ${ }^{87} \mathrm{Sr} /{ }^{86} \mathrm{Sr}$ values reflect dietary strontium, which can be used to infer place of residence, in the last years of life. In 
Table 2. Radiogenic Isotopic Data from Individual 3N.7 and Burial Soils from Calate.

\begin{tabular}{|c|c|c|c|c|}
\hline Laboratory Number & Specimen Number & Sample Type & $\mathrm{Ca} / \mathrm{P}$ & ${ }^{87} \mathrm{Sr} /{ }^{86} \mathrm{Sr}$ \\
\hline ACL-2780 & CALA-0008 & Lower right molar 2 (deciduous) & 2.0 & 0.70817 \\
\hline ACL-2786 & CALA-0007 & Right rib & 2.0 & 0.70805 \\
\hline ACL-2764 & CALA-0001 & Soil sample & NA & 0.70926 \\
\hline ACL-2765 & CALA-0002 & Soil sample & NA & 0.70891 \\
\hline ACL-2767 & CALA-0005 & Soil sample & NA & 0.70868 \\
\hline ACL-2769 & CALA-0005 & Soil sample & NA & 0.70840 \\
\hline ACL-2771 & CALA-0007 & Soil sample & NA & 0.70930 \\
\hline ACL-2773 & CALA-0008 & Soil sample & NA & 0.70938 \\
\hline
\end{tabular}

contrast, enamel does not remodel, so enamel ${ }^{87} \mathrm{Sr} /{ }^{86} \mathrm{Sr}$ values reflect dietary strontium sources, and place of residence, in the first years of life. We analyzed one enamel sample (from a deciduous second molar) and one bone sample (from a rib fragment).

Elemental concentrations of calcium and phosphorus in these samples are shown in Table 2; in human bone, biogenic $\mathrm{Ca} / \mathrm{P}=2.1$, and in these samples, $\mathrm{Ca} / \mathrm{P}=2.0$, indicating biogenic enamel and bone values. Radiogenic strontium isotope values from this individual are used to infer geographic origins during enamel and bone formation. Given the uninhabited and potentially uninhabitable nature of much of Calate, we did not generate bioavailable strontium isotope data from agricultural fields. Instead, we collected soil samples from the burials themselves. In the burial soil samples, mean ${ }^{87} \mathrm{Sr} /{ }^{86} \mathrm{Sr}=0.70899 \pm 0.00039(1 \sigma, n=6$; Table 1). Farther inland, modern and archaeological fauna from the San Pedro de Atacama oases exhibit ${ }^{87} \mathrm{Sr} /{ }^{86} \mathrm{Sr}=0.70764 \pm 0.000013$ $(1 \sigma, n=3)$ in modern and archaeological faunal samples from San Pedro de Atacama (Knudson and Price 2007); similar values are observed in groundwater from the Salar de Atacama (Boschetti et al. 2007). On the northern and central Chilean coast, ${ }^{87} \mathrm{Sr} /{ }^{86} \mathrm{Sr}$ values in bedrock samples are lower (Kramer et al. 2005; Parada et al. 1999). However, we note that both sea spray and consumption of high-strontium marine resources could contribute a marine seawater value of approximately ${ }^{87} \mathrm{Sr} /{ }^{86} \mathrm{Sr}=0.7092$ (Veizer 1989).

Because ${ }^{87} \mathrm{Sr} /{ }^{86} \mathrm{Sr}$ values in the body reflect the strontium consumed and imbibed during enamel and bone formation, we found that the most likely high-strontium sources in this individual's diet were terrestrial sources including water or salt; other likely dietary sources such as maize kernels or animal flesh are generally low in strontium. Finally, before and during the weaning process, breast milk would have been the primary food source; although this milk is not high in strontium, it would have been the primary strontium source for the infant, reflecting the strontium sources in the milk provider's diet. Fish and marine products likely contributed little strontium to the diet, unless whole fish were consumed, either dried or fresh, which contributed large amounts of calcium and strontium through the consumption of fish bones. In this case, we would expect that the consumption of marine fish bones would contribute a marine seawater value of approximately ${ }^{87} \mathrm{Sr} /{ }^{86} \mathrm{Sr}=0.7092$ (Veizer 1989). In the rest of this section, we analyze the consumption of marine products through carbon and nitrogen isotope analyses to infer the paleodiet.

It is worth noting that the two values of radiogenic strontium obtained from 3N.7 (Table 2) do not fit completely into expectations for either a coastal or an interior origin. Although they are consistent with the burial soil samples, the archaeological context does not point to "local" origins in this well-traveled area. There is also little evidence for diagenetic contamination, although this could also explain the similarities with the soil samples. Given the early formation of deciduous dental enamel, these results reflect an experience in utero and suggest the possibility that the mother may have been involved in recurrent movements during pregnancy and during the child's infancy while breastfeeding. The similar value in the rib bone, which reflects the child's life experiences, provides the first suggestion 


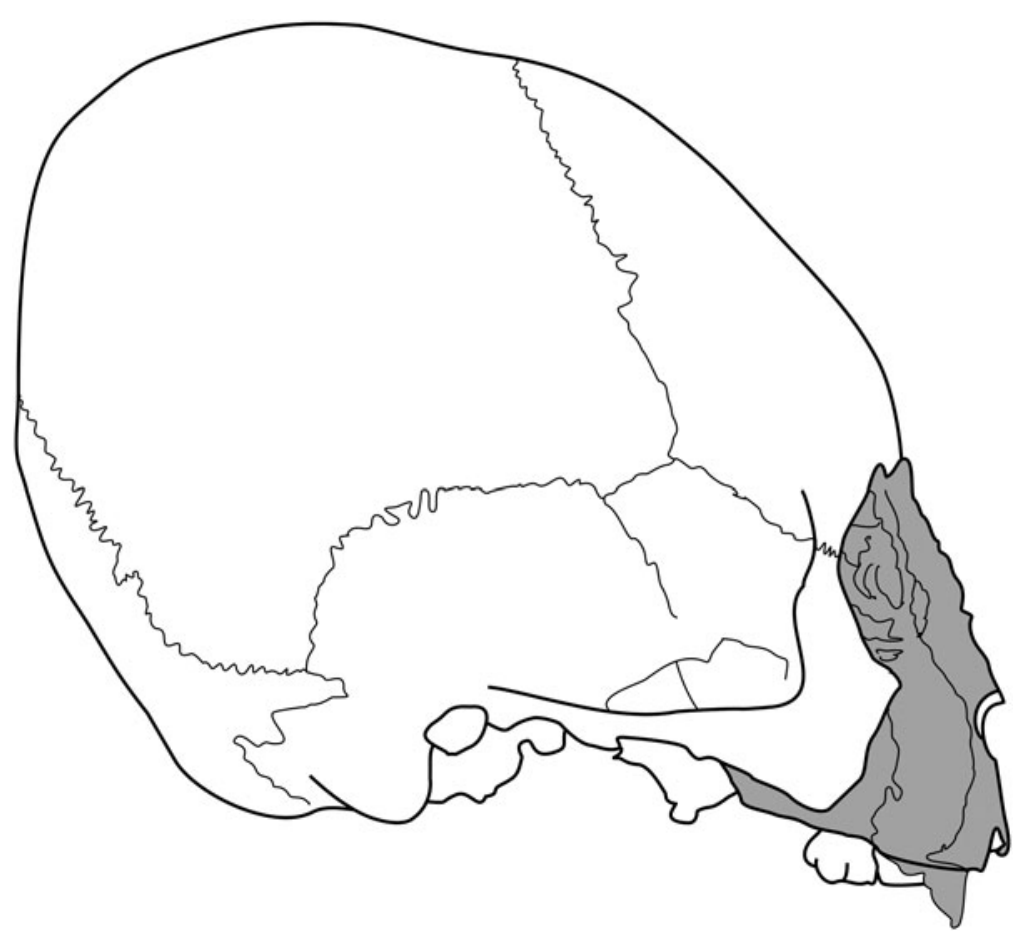

Figure 3. Illustration of tabular oblique cranial modification in the cranium of individual 3N.7.

that this individual, despite their age, could have been a regular traveler with their family group. These radiogenic strontium values might correspond to an intermediate between two possible origins, representing expansive evidence for contacts and movement in the body. The child's body, in effect, integrated both coastal and interior patterns.

The skeletal remains showed evidence of intentional cranial modification during infancy. Unlike cradleboarding practices, the forms of head shaping practiced in the Andes do not restrain children. As such, and despite the potentially high mobility of their childhood, someone took time to regularly bind this child's head, ultimately producing a significant and permanently visible alteration to its natural form. Varied patterns of modification are seen throughout Tarapacá, some reflecting great diversity in practices with others showing no evidence of modification (e.g., González-Ramírez et al. 2019; Uribe et al. 2015). Calate-3N.7 had pronounced tabular oblique cranial shaping (Figure 3), in which compressive pressures are applied to the front and back of the head while not restricting lateral growth. This practice serves to demarcate social identity within a framework of mobility and variation and suggests that this child's head shaping would have been noticeable and signaled some form of group affiliation as they traversed the desert.

Taken together, we can see the radiogenic strontium values and intentionally shaped head as immutable markers of infancy that this individual carried while traveling with the family group across the desert; as such, these markers can illustrate aspects of this earliest period of life. Notably, while the shaped head is likely tied to heritage, the strontium values give hints to the varied landscapes inhabited by this child and contribute to our understanding of the potential regularized, interzonal movement that characterized Tarapacá's Late Formative period.

\section{Childhood}

To explore the childhood experience of Calate-3N.7, we turn to a series of heath indicators and to stable carbon and nitrogen isotope values indicative of dietary patterns. We focus 
here on the developmental period following birth and the earliest phase of infancy, exploring the health and diet of this young individual before an early death.

Examining a series of skeletal health indicators allows us to glimpse the experience of childhood through the body (Halcrow and Ward 2018; Mays et al. 2017). Although questions of frailty or the "osteological paradox" inherently complicate analyses of paleopathological indicators (DeWitte and Stojanowski 2015; Wood et al. 1992), considerations of these data points can provide us with hints as to individual health. The teeth of Calate-3N.7 show no evidence of oral pathologies or of enamel hypoplasia, a common defect related to acute moments of dietary stress. Similarly, there are no signs of childhood diseases or other general indicators of systemic stress on the skeletal remains. Data from coastal individuals have suggested a pattern of early weaning and the gradual replacement of milk with marine products, providing a nutritionally sound transition that served to protect infants from malnutrition (King et al. 2018; Smith et al. 2017). This might have contributed to Calate-3N.7's health if the child's family had engaged in these coastal practices. Finally, there was no evidence of violent or accidental traumas producing injury visible on the skeleton, despite the likelihood of a mobile life (Glencross 2011).

Analyses of stable isotopes of carbon and nitrogen in bone collagen and hydroxyapatite and their subsequent Bayesian modeling permit probabilistic statements about the quantitative makeup of this individual's childhood diet. Stable isotope and modeled dietary intake for individual Calate-3N.7 are presented in Table 3. The largest contributor to this child's diet was $\mathrm{C}_{3}$ plants (including the common algarrobo tree-Prosopis spp.), which accounted for just under $40 \%$ of dietary calories. The other significant dietary contributor, and the principal source of dietary protein, was marine fauna, which made up roughly one-third of consumed calories and more than $60 \%$ of protein intake, although some residual isotopic (trophic) effects attributable to breastfeeding cannot be ruled out. When these values are compared to the broad sweep of paleodietary data for Formative period
Table 3. Stable Carbon and Nitrogen Isotope Data from Individual 3N.7 from Calate.

\begin{tabular}{lr}
\hline Isotopic Data (\%o) & \\
\hline$\delta^{13} \mathrm{C}_{\text {co-PDB }}$ & -14.2 \\
$\delta^{15} \mathrm{~N}_{\text {co-AIR }}$ & 22.6 \\
$\delta^{13} \mathrm{C}_{\text {ap-PDB }}$ & -11.8 \\
$\Delta^{13} \mathrm{C}_{\text {ap-co }}$ & 2.4 \\
\hline
\end{tabular}

Modeled Dietary Intake (\%)

\begin{tabular}{lc}
\hline $\mathrm{C}_{3}$ plants & $39.6 \pm 16.5$ \\
$\mathrm{C}_{4} / \mathrm{CAM}$ plants & $7.5 \pm 6.2$ \\
Legumes & $13.0 \pm 11.5$ \\
Terrestrial animals & $7.4 \pm 7.1$ \\
Marine animals & $32.6 \pm 11.8$ \\
\hline
\end{tabular}

individuals from northern Chile, they approximate the typical values of coastal populations, particularly individuals from the mouth of the Loa River (Pestle et al. 2015) and those seen in other Formative period individuals from the Atacama more broadly (Santana-Sagredo et al. 2012, 2015; Uribe et al. 2020). Indeed, the minor role of $\mathrm{C}_{4} / \mathrm{CAM}$ plants (maize, in particular) and the dominance of marine fauna as a protein source appear as common themes of the diet of coastal and coastal-adjacent/linked populations in the Atacama/Loa and Tarapacá regions of the Formative. Beyond these broad similarities, we note that these values also approximate those of individuals from the oases of Ancachi and Quillagua, which we (and others) have previously argued was a node in the broader systems of interregional exchange; these individuals possessed a set of dietary habits unique in the broader Atacama (Pinder et al. 2019). Although these data do not prove that this child spent time in these locales, the diet situates this individual within the continuum of diets seen along the greater extent of the Loa River.

In concert, this set of data provides evidence of a healthy and mobile childhood, albeit a brief one. The paleopathological data suggest a lack of exposure to stressors or injury that would have marked the skeleton, suggesting that even if travel was a regular feature of this individual's life, its impact was not seen in these bioarchaeologically visible indicators. Marine resources make up almost one-third of this individual's diet, serve as the largest source 
of dietary protein, and synchronize well with the lack of dental caries. As such, the evidence here suggests a life with regular and pronounced consumption of marine resources and traditional inland foods, again reflecting the presumed mobility of this individual with the family group. These data do not obscure the fact that this child died at a young age in the open desert, something that may have resulted from the arduous nature of travel in these extreme environments. The patterns, therefore, reflect both the individual experience of movement through Calate and the broader implications of life in an increasingly complex and interconnected Formative period.

\section{After Death}

Sometime during childhood, without leaving physical evidence as to cause, this child died and was buried alongside a trail in Calate. Typical Formative period burial practices (e.g., GonzálezRamírez et al. 2019) were afforded to 3 N.7 despite the circumstances. The grave was set about $10 \mathrm{~m}$ from the nearest trail where it remained undisturbed over the centuries. A small circular pile of stones covered this primary burial. The burial, like the body, provides evidence of interactions and complex regional networks.

Unlike other travelers who suffered a similar fate in this unforgiving space, considerable effort was made to dig a grave into rocky ground, dress the child, and bury numerous offerings next to the small body. The burial reflects the ways that this child died as a traveler and as an active participant in these moments of mobility, not as one deprived of agency because of age. Although grave goods can serve as gendered indicators, given the young age at death we have no real information about the experience of their sex in life. The body was dressed as we would expect from any member of a group of travelers. In addition to a thick blanket laid at the bottom of the tomb, the child wore a woven tunic made of camelid fiber and retained fragments of a feather garment.

The grave included a varied suite of goods that also document exchange networks during the Late Formative (Supplemental Table 1). Of note, the depth of the grave and the evidence of closure with a series of larger rocks suggest the

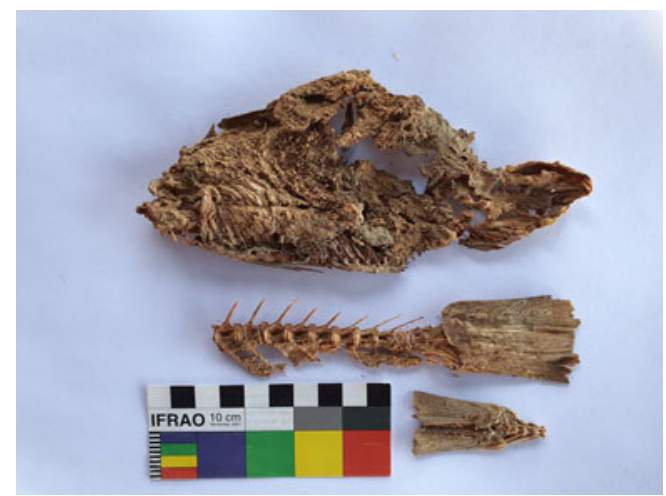

Figure 4. Dried fish (Cilus gilberti?) found in the grave of individual 3N.7. (Color online)

burial was a single event of bereavement and burial, and not a long-term use of the tomb as a sacred space for offerings as seen at other sites at Calate (Pimentel et al. 2017). Some offerings did speak to a coastal connection-for example, a feathered garment, a type that has been seen before in traveler burials (Briones et al. 2005), remains of dried fish, and fish vertebrae of varied species (Labarca and Calás 2012; Figure 4).

A larger number of objects, however, reflect connections to the interior; for example, the maize (Zea mays; García 2010). Complete ceramic bottles (Figure 5) from the Tarapacá oases more than $100 \mathrm{~km}$ away were placed on the body, one with algarrobo pods and camelid feces inside. A basket containing a miniature ceramic bowl was placed next to the skull. These ceramics are of the type known as Quillagua Tarapacá Café Amarillento (QTC), a style commonly found in Late Formative centers from Arica to the Loa (Uribe 2009; Uribe and Ayala 2004). The burial also included eight arrow shafts, some with delicate feathered fletching (Figure 6). The textiles in the grave are associated with the traditions of the Valles Occidentales or Quillagua, including textile technologies documented at Caserones and Tarapacá-40 (Agüero 2012; Oakland 2000); Calate-3N.7 bears similarities to graves from Tarapacá-40 in the burial style, ceramics, and textiles.

The distal fragment of a polished black ceramic pipe with a zoomorphic modeling of a feline with traces of red and green pigments was found near the cranium (Figure 7). Pipes are common during 


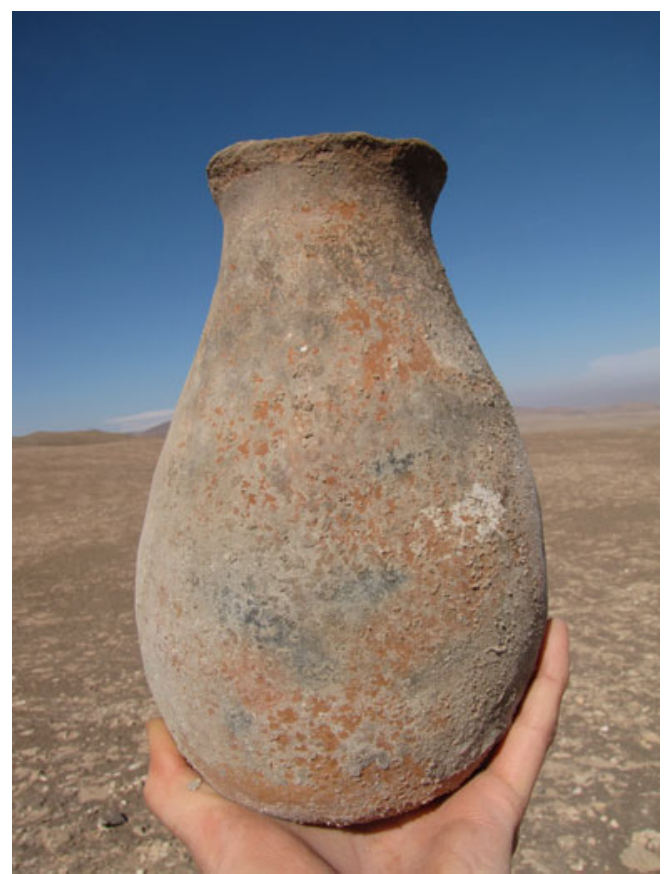

Figure 5. "Florero" ceramic bottle (Quillagua Tarapacá Café Amarillento) buried with individual 3N.7. (Color online)

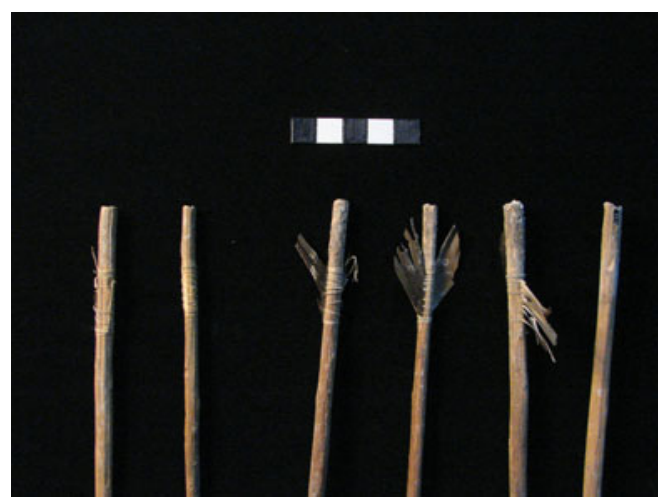

Figure 6. Details of fletching on arrow shafts buried with individual 3N.7. (Color online)

the Formative in the southern Andes, and there is evidence of them from the Pacific coast, across the Atacama, and into northwestern Argentina (e.g., Carrasco et al. 2015; Gili et al. 2017). The iconography links this to the San Francisco Complex of northwestern Argentina. As such, this pipe was carried through arduous mountain passes over a distance of more than 700 linear $\mathrm{km}$. Although it is unlikely that the group traveling with this child procured all the elements in this grave, the

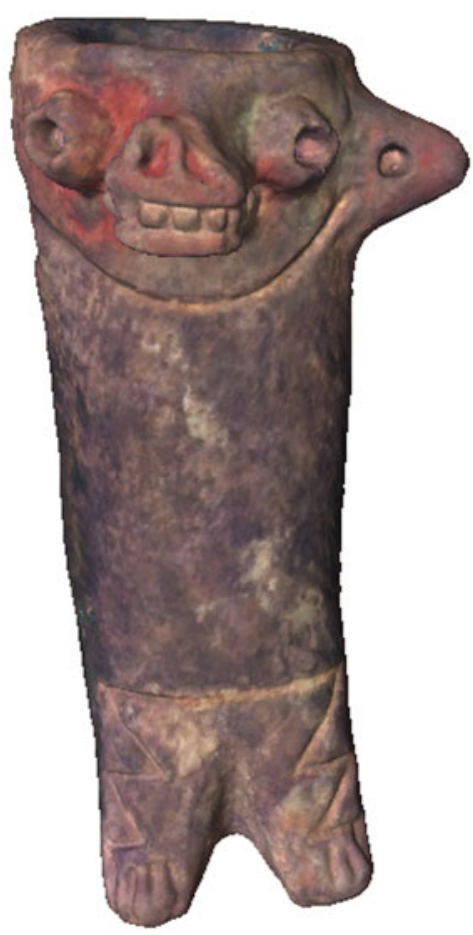

Figure 7. Rendering of San Francisco pipe fragment from a 3D scan. (Color online)

objects were all left together in this mortuary context, reflecting the larger interconnectedness of travelers in this era.

In sum, much like what was reflected in the body, the material culture showed differential relationships with the interior oases, the Pacific coast, and the eastern slope of the Andes. The grave also reflects this intercultural development. Although the context overwhelmingly speaks to the interior, numerous ties engage this child with the broader region and social environment, including the way the pipe fragment speaks to us of potential chains of relationships. In totality, the material goods demonstrate ways in which this child inhabited both coastal and interior worlds, despite likely coming from the interior. Ultimately, this child's body and grave embody both one life and the thick interaction networks between the interior and the coast during the Formative period.

\section{Conclusions}

Calate was an important and long-standing internodal site of the precolumbian road network in 
the Atacama, where multiple roads that flowed to and from the mouth of the Loa River or nearby sectors converged and, with them, brought people and things from diverse spaces across the desert. As Gallardo and colleagues (2017:253) note, "Exchange enabled the integration of communities inhabiting northwestern Argentina, the Bolivian altiplano, the Amazon, and the forested oases of Tarapacá." Importantly, it is not only the material goods but also the human interactions that enabled this integration. The evidence from Calate speaks to these deep triadic social relations between coastal groups, Atacameños, and Tarapaqueños and importantly suggests the specificity and variability of these relationships in the Formative. Considering the suite of data generated here, we can see a child whose life was spent not only moving through these desert routes but also traveling and interacting in the world of adults and in the nodes and internodal spaces between the coast and the interior. The interactions that were part of these itineraries across the desert are present in both the mortuary space and in the people who engaged in this travel.

This child could not complete the trip across Calate along this route, which was probably similar to others they had crossed in their life. Considering the embodied experience of living this mobile life through the remains of 3 N.7, we can see how the body and the grave demonstrate the social character of movement in the Late Formative period. For this child, our data suggest regular movements between the coast and interior and the material records of the cultures with which the individual interacted in his or her short life. This opens the possibility of familial caravan movement, perhaps even focused on the movement of fish. Like this child's diet, which was marked by the consumption of resources from both coastal and interior environments, we can see the way that the elements of the grave were representative of the extensive networks of exchange that characterized the Formative period.

The burial of $3 \mathrm{~N} .7$ gives us a remarkable account of the wide extension and intensity of the exchange networks in which groups of this era participated. Engagement with travel and interaction functioned not just for resource exchange; the travel itself served to extract, ritualize, and territorialize the larger spaces of the desert (Pimentel and Ugarte 2017:34). This shows us an important fluidity and highlights the greater extent of these networks, which reached weblike from the eastern slopes of the Andes to the Pacific coast. Rather than a direct relationship between these extremes, what this body reflects is the ways in which travelers coming from the coast are part of a regular multidirectional chain of exchanges that intensified during northern Chile's Formative period.

The mortuary space constructed for $3 \mathrm{~N} .7$ emphasizes the recurrent and deep network in which these travelers across Calate were enmeshed. Importantly, these rituals created embodied networks of shared histories and relationships from which a communal identity was built. This child fully engaged in the labor of trans-desert travel and their brief life was marked by a permanent integration of the different social and environmental worlds found along these routes. Although the material record of this grave and others along desert routes speaks to the transactions that occurred as part of these movements, there are more to these processes. The child's body gives evidence of the impact of these exchanges - living in varied spaces, consuming varied foods, interacting with varied people and cultures. These travelers served as a direct link in the chains of long-distance exchange. The materials of the tomb therefore show evidence not only of interaction, reciprocity, and economy but also of the intimate social networks of individual lives.

Considering both the scale of a life and the broader multiscalar narrative of the Formative period, 3N.7 serves as more than as a vessel in which the variety and complexity of the era are reflected. Perhaps 3N.7 stands as a representation, through the child's body and the idealized nature of grave construction, of what the era was. Is it possible that this child's body, like other individual lives, can also suggest an understanding of the nature of travel in this time and of the more human aspects of this economic exchange? If so, this would allow us to consider the broader cultural impacts of these relationships and the intersections between different identities. While individual and familial ties 
likely manifest in the brief life of 3N.7 and in mourning their loss, examination of these linkages may also serve to define new spaces where people of the Formative thrived.

This leads to the idea that the Formative period may have witnessed the creation of hybrid or intercultural identities that functioned as an amalgamation of varied cultures. In these new identities, the period created something new that allowed for the florescence and establishment of complexity resulting not just from exchange but also from myriad prolonged and developed relationships. Calate-3N.7 then, is not a unique individual in the spectrum of the Formative, but rather likely speaks to this possibility of opening new spaces between formal interactions. Ultimately, the life and death of this child serve to illustrate the entanglement of interregional connections, individual life experience, and individual and group identity expression.

Acknowledgments. This research was conducted under FONDECYT 1181750 and 1090762 and CMN Ord No. 3344/09. It was also supported by the UC Merced Center for the Humanities and by Dumbarton Oaks. We appreciate the comments and support of José F. Blanco, Gloria Cabello, Francisco Gallardo, Mark Hubbe, Sarah Schrader, and the Museo Gustavo Le Paige. Finally, we would like to acknowledge the thoughtful reviewer commentaries that helped improve the article.

Data Availability Statement. The text includes the data used in this article. The remains of individual 3N.7 are curated at the Museo Gustavo Le Paige of the Universidad Católica del Norte, San Pedro de Atacama, Chile. Further details concerning the radiocarbon dates and stable and radiogenic isotope results can be obtained from the corresponding author.

Supplemental Material. For supplemental material accompanying this article, visit https://doi.org/10.1017/laq.2021.56.

Supplemental Table 1. Grave Inventory for Calate 3N.7.

\section{References Cited}

Adán, Leonor, Simón Urbina, Constanza Pellegrino, and Carolina Agüero

2013 Aldeas en los bosques de Prosopis: Arquitectura residencial y congregacional en el período Formativo tarapaqueño. Estudios Atacameños 45:75-94.

Adán, Leonor, Mauricio Uribe, and Simón Urbina

2007 Arquitectura pública y doméstica en las quebradas de Tarapacá: Asentamiento y dinámica social en el Norte Grande de Chile. In Procesos sociales prehispánicos en el sur andino: La vivienda, la comunidad y el territorio, edited by Axel Nielsen, Clara Rivolta, Pablo Mercolli, Maria Magdalena Vásquez, and Verónica Seldes, pp. 183-206. Editorial Brujas, Córdoba, Argentina.
Agarwal, Sabrina

2016 Bone Morphologies and Histories: Life Course Approaches in Bioarchaeology. American Journal of Physical Anthropology 159:S130-S149.

Agarwal, Sabrina, and Bonnie Glencross (editors)

2011 Social Bioarchaeology. Blackwell Studies in Global Archaeology. Wiley-Blackwell, Malden, Massachusetts.

Agüero, Carolina

2012 Textiles del asentamiento Caserones y su cementerio: Significado social y político para la población tarapaqueña durante el período Formativo (norte de Chile). Revista Chilena de Antropología 26:59-94.

Agüero, Carolina, and Bárbara Cases

2004 Quillagua y los textiles formativos del Norte Grande de Chile. Chungara Vol. Especial:599-617.

Aldunate, Carlos, and Victoria Castro

1981 Las chullpas de Toconce y su relación con el poblamiento altiplánico en el Loa superior. Ediciones Kultrun, Santiago.

Balcaen, Liev, Isabel de Schrijver, Luc Moens, and Frank Vanhaecke

2005 Determination of the ${ }^{87} \mathrm{Sr} /{ }^{86} \mathrm{Sr}$ Isotope Ratio in USGS Silicate Reference Materials by Multi-Collector ICP-Mass Spectrometry. International Journal of Mass Spectrometry 242:251-255.

Beauchesne, Patrick, and Sabrina Agarwal

2018 Children and Childhood in Bioarchaeology. University Press of Florida, Gainesville.

Bentley, R. Alexander

2006 Strontium Isotopes from the Earth to the Archaeological Skeleton: A Review. Journal of Archaeological Method and Theory 13:135-187.

Boschetti, Tiziano, Gianni Cortecci, Maurizio Barbieri, and Mario Mussi

2007 New and Past Geochemical Data on Fresh to Brine Waters of the Salar de Atacama and Andean Altiplano, Northern Chile. Geofluids 7(1):33-50.

Briones, Luis, Lautaro Núñez, and Vivien Standen

2005 Geoglifos y tráfico prehispánico de caravanas de llamas en el Desierto de Atacama (norte de Chile). Chungara 37:195-223.

Buikstra, Jane, and Douglas Ubelaker

1994 Standards for Data Collection from Human Skeletal Remains. Arkansas Archaeological Survey, Fayetteville.

Carrasco, Carlos, Javier Echeverría, Benjamín Ballester, and Hermann Niemeyer

2015 De pipas y sustancias: Costumbres fumatorias durante el período Formativo en el litoral del Desierto de Atacama. Latin American Antiquity 26:143-161.

Cases, Bárbara, Charles Rees, Gonzalo Pimentel, Rafael Labarca, and Daniela Leiva

2008 Sugerencias desde un contexto funerario en un "espacio vacío" del Desierto de Atacama. Boletín del Museo Chileno de Arte Precolombino 13:51-70.

Castro, Victoria, José Berenguer, Francisco Gallardo, Agustín Llagostera, and Diego Salazar

2016 Vertiente Occidental Circumpuñena: Desde las sociedades posarcaicas hasta las preincas (ca. 1.500 años a.C. a 1.470 años d.C.). In Prehistoria en Chile: Desde sus primeros habitantes hasta los Incas, edited by Fernanda Falabella, Mauricio Uribe, Lorena Sanhueza, Carlos Aldunate, and Jorge Hidalgo, pp. 239-283. Editorial Universitaria, Santiago.

Cavagnoud, Robin, Charles-Édouard de Suremain, and Palmira La Riva González (editors) 
2013 Infancia y niños en las sociedades andinas contemporáneas. Bulletin de l' Institut Francais d' Etude Andines 42:323-585.

DeWitte, Sharon, and Christopher Stojanowski

2015 The Osteological Paradox 20 Years Later: Past Perspectives, Future Directions. Journal of Archaeological Research 23:397-450.

Fernandes, Ricardo, Andrew Millard, Marek Brabec, MarieJosée Nadeau, and Pieter Grootes

2014 Food Reconstruction Using Isotopic Transferred Signals (FRUITS): A Bayesian Model for Dietary Reconstruction. PLoS ONE 9(2):e87436.

Gallardo, Francisco

2017 Arqueología de los intercambios recíprocos: Costa y oasis del Río Loa medio e inferior (500AC-700DC). In Monumentos funerarios en la costa del Desierto de Atacama, edited by Francisco Gallardo, Benjamín Ballester, and Nicole Fuenzalida, pp. 15-22. Serie Monográfica de la Sociedad Chilena de Arqueología No. 7. CIIR \& SCHA, Santiago.

Gallardo, Francisco, Itací Correa, Gonzalo Pimentel, and José F. Blanco

2017 Consumption Consumes: Circulation, Exchange, and Value of San Pedro de Atacama Black Polished Ceramics. Latin American Antiquity 28:252-268.

García, Magdalena

2010 Contextos vegetales de Calate, eje Quillagua-Caleta Huelén (curso inferior río Loa). Submitted to FONDECYT, Project No. 1090762. Copies available from FONDEYCT.

García, Magdalena, Alejandra Vidal, Valentina Mandakovic, Antonio Maldonado, Maria Paz Peña, and Eliana Belmonte

2014 Alimentos, tecnologías vegetales y paleoambiente en las aldeas Formativas de la Pampa del Tamarugal, Tarapacá (ca. 900 aC-800 dC). Estudios Atacameños 47:33-58.

Gili, Francisco, Javier Echeverría, Emily Stovel, Michael Deibel, and Hermann Niemeyer

2017 Las pipas en el Salar de Atacama: Reevaluando su origen y uso. Estudios Atacameños 54:37-64.

Glencross, Bonnie

2011 Skeletal Injury across the Life Course: Towards Understanding Social Agency. In Social Bioarchaeology, edited by Sabrina Agarwal and Bonnie Glencross, pp. 390-409. Wiley Blackwell, Oxford.

González-Ramírez, Arturo, Aryel Pacheco, Arturo Sáez, and Ivan Arregui

2019 Infants from the Tarapacá 40 Cemetery (Northern Chile, Formative Period, 1000 BC-AD 600). International Journal of Osteoarchaeology 29:874-880.

Halcrow, Siân, and Stacy Ward

2018 Children in Bioarchaeology and Forensic Anthropology. In Encyclopedia of Global Archaeology (Living Edition), edited by Claire Smith. Springer, Cham, Switzerland. DOI:10.1007/978-3-319-51726-1, accessed December 29, 2019.

Hillson, Simon

1996 Dental Anthropology. Cambridge University Press, New York.

Hogg, Alan, Timothy Heaton, Quan Hua, Jonathan Palmer, Chris Turney, John Southon, Alex Bayliss et al.

2020 SHCal20 Southern Hemisphere Calibration, 0-55,000 Years Cal BP. Radiocarbon 62:759-778

King, Charlotte, Siân Halcrow, Andrew Millard, Darren Gröcke, Vivien Standen, Marco Portilla, and Bernardo Arriaza

2018 Let's Talk about Stress, Baby! Infant-Feeding Practices and Stress in the Ancient Atacama Desert, Northern
Chile. American Journal of Physical Anthropology 166:139-155.

Knudson, Kelly, and T. Douglas Price

2007 Utility of Multiple Chemical Techniques in Archaeological Residential Mobility Studies: Case Studies from Tiwanaku- and Chiribaya-Affiliated Sites in the Andes. American Journal of Physical Anthropology 132:25-39.

Knudson, Kelly, H. M. Williams, Jane Buikstra, Paula Tomczak, Gwyneth Gordon, and Ariel Anbar

2010 Introducing $\delta^{88} /{ }^{86} \mathrm{Sr}$ Analysis in Archaeology: A Demonstration of the Utility of Strontium Isotope Fractionation in Paleodietary Studies. Journal of Archaeological Science 27:2352-2364.

Kramer, Wolfgang, Wolfgang Siebel, Rolf Romer, Günther Haase, Martin Zimmer, and Ralph Ehrlichmann

2005 Geochemical and Isotopic Characteristics and Evolution of the Jurassic Volcanic Arc between Arica (18'30'S) and Tocopilla ( $\left.22^{\circ} \mathrm{S}\right)$, North Chilean Coastal Cordillera. Chemie der Erde-Geochemistry 65(1): $47-78$.

Krueger, Harold

1991 Exchange of Carbon with Biological Apatite. Journal of Archaeological Science 18:355-361.

Labarca, Rafael, and Elisa Calás

2012 Informe arqueofaunístico de yacimientos asociados a rutas prehispánicas en la Región de Antofagasta, Chile. Submitted to FONDECYT, Project No. 1090762. Copies available from FONDEYCT.

Lee-Thorp, Julia

1989 Stable Carbon Isotopes in Deep Time: The Diets of Fossil Fauna and Hominids. University of Cape Town, Cape Town, South Africa.

Lewis, Charlotte

2014 Interdisciplinarity, Archaeology and the Study of Medieval Childhood. In Medieval Childhood: Archaeological Approaches, edited by Dawn Hadley and K. A. Hemer, pp. 145-170. Oxbow, Oxford.

Lewis, Jamie, A. W. G. Pike, Christopher Coath, and Richard Evershed

2017 Strontium Concentration, Radiogenic $\left({ }^{87} \mathrm{Sr} /{ }^{86} \mathrm{Sr}\right)$ and Stable $\left(\delta^{88} \mathrm{Sr}\right)$ Strontium Isotope Systematics in a Controlled Feeding Study. STAR: Science \& Technology of Archaeological Research 3:53-65.

Longin, Robert

1971 New Method of Collagen Extraction for Radiocarbon Dating. Nature 230:241-242.

Lovell, Nancy

1997 Trauma Analysis in Paleopathology. Yearbook of Physical Anthropology 40:139-170.

Lumbreras, Luis

2006 Un Formativo sin cerámica y cerámica preformativa Estudios Atacameños 32:11-34.

Marklein, Kathryn, Christina Torres-Rouff, Laura King, and Mark Hubbe

2019 The Precarious State of Subsistence: Reevaluating Dental Pathological Lesions Associated with Agricultural and Hunter-Gatherer Lifeways. Current Anthropology 60:341-368.

Mays, Simon, Rebecca Gowland, Siân Halcrow, and Eileen Murphy

2017 Child Bioarchaeology: Perspectives on the Past 10 Years. Childhood in the Past 10:38-56.

Meskell, Lynn

2000 Writing the Body in Archaeology. In Reading the Body: Representations and Remains in the 
Archaeological Record, edited by Allison Rautman, pp. 13-21. University of Pennsylvania Press, Philadelphia.

Moore, Jonathan, and Brice Semmens

2008 Incorporating Uncertainty and Prior Information into Stable Isotope Mixing Models. Ecology Letters 11:470-480.

Muñoz, Ivan, Carolina Agüero, and Daniela Valenzuela

2016 Poblaciones prehispanicas de los Valles Occidentales del norte de Chile: Desde el periodo Formativo al Intermedio Tardío (ca. 1.000 años a.C. a 1.400 años d.C.). In Prehistoria en Chile: Desde sus primeros habitantes hasta los Incas, edited by Fernanda Falabella, Mauricio Uribe, Lorena Sanhueza, Carlos Aldunate, and Jorge Hidalgo, pp. 181-238. Editorial Universitaria, Santiago.

Núñez, Lautaro, Isabel Cartajena, Carlos Carrasco, Patricio de Souza, and Martin Grosjean

2006 Emergencia de comunidades pastoralistas formativas en la Puna de Atacama. Estudios Atacameños 32:93-117.

Núñez, Lautaro, and Tom Dillehay

1979 Movilidad giratoria armonía social y desarrollo en los Andes Meridionales: Patrones de tráfico e interacción económica (ensayo). Universidad del Norte, Antofagasta, Chile.

Núñez, Lautaro, and Calogero Santoro

2011 El tránsito Arcaico-Formativo en la Circumpuna y Valles Occidentales del Centro Sur Andino: Hacia los cambios "neolíticos." Chungara 43:487-530.

Oakland, Amy

2000 Andean Textiles from Village and Cemetery: Caserones in the Tarapaca Valley, North Chile. In Beyond Cloth and Cordage: Archaeological Textile Research in the Americas, edited by Penelope Drooker and Laurie Webster, pp. 229-251. University of Utah Press, Salt Lake City.

Odone, Carola

2017 El valle de Quillagua (siglos XVI y XX). Palimpsesto Número Especial:120-150.

Parada, Miguel Ángel, Jan Nyström, and Beatriz Levi

1999 Multiple Sources for the Coastal Batholith of Central Chile $\left(31-34^{\circ} \mathrm{S}\right)$ : Geochemical and $\mathrm{Sr}-\mathrm{Nd}$ Isotopic Evidence and Tectonic Implications. Lithos 46:505-521.

Pestle, William

2010 Diet and Society in Prehistoric Puerto Rico, An Isotopic Approach. PhD dissertation, Department of Anthropology, University of Illinois, Chicago.

Pestle, William, Christina Torres-Rouff, Francisco Gallardo, Benjamín Ballester, and Alejandro Clarot

2015 Mobility and Exchange among Marine HunterGatherer and Agropastoralist Communities in the Formative Period Atacama Desert. Current Anthropology 56:121-133.

Pestle, William, Christina Torres-Rouff, and Mark Hubbe

2016 Modeling Diet in Times of Change: The Case of Quitor, San Pedro de Atacama, Chile. Journal of Archaeological Science: Reports 7:82-93.

Pestle, William, Christina Torres-Rouff, Mark Hubbe, and Erin Smith

2017 Eating in or Dining out: Modeling Diverse Dietary Strategies in Middle Period San Pedro de Atacama, Chile. Archaeological and Anthropological Sciences 9:1363-1377.

Pimentel, Gonzalo, Charles Rees, Patricio de Souza, and Lorena Arancibia

2011 Viajeros costeros y caravaneros: Dos estrategias de movilidad en el período Formativo del Desierto de Atacama, Chile. In En Ruta: Arqueología, Historia y Etnografía del Tráfico Sur Andino, edited by Lautaro Núñez and Axel Nielsen, pp. 43-81. Encuentro Grupo Editor, Córdoba, Argentina.

Pimentel, Gonzalo, and Mariana Ugarte

2017 La agencia costera en la pampa de Desierto de Atacama. In Monumentos funerarios en la costa del Desierto de Atacama, edited by Francisco Gallardo, Benjamín Ballester, and Nicole Fuenzalida, pp. 25-36. Serie Monográfica de la Sociedad Chilena de Arqueología No. 7. CIIR \& SCHA, Santiago.

Pimentel, Gonzalo, Mariana Ugarte, José Blanco, Christina Torres-Rouff, and William Pestle

2017 Calate: De lugar desnudo a laboratorio arqueológico de la movilidad y el tráfico intercultural prehispánico en el Desierto de Atacama (ca. 7000 AP-550 AP). Estudios Atacameños 56:23-58.

Pinder, Danielle, Francisco Gallardo, Gloria Cabello, Christina Torres-Rouff, and William Pestle

2019 An Isotopic Study of Dietary Diversity in Formative Period Ancachi/Quillagua, Atacama Desert, Northern Chile. American Journal of Physical Anthropology 170:613-621.

Rivera, Mario

2002 Historias del desierto: Arqueología el norte de Chile. Editorial del Norte, La Serena, Chile.

Santana-Sagredo, Francisca, María José Herrera, and Mauricio Uribe

2012 Acercamiento a la paleodieta en la costa y quebradas tarapaqueñas durante el periodo Formativo: Análisis de isótopos estables a partir de tres casos de estudio. Boletín de la Sociedad Chilena de Arqueología 42:109-126.

Santana-Sagredo, Francisca, Mauricio Uribe, María José Herrera, Rodrigo Retamal, and Sergio Flores

2015 Dietary Practices in Ancient Populations from Northern Chile during the Transition to Agriculture (Tarapacá Region, 1000 BC-AD 900). American Journal of Physical Anthropology 158:751-758.

Slovak, Nicole, and Adina Paytan

2011 Applications of Sr Isotopes in Archaeology. In Handbook of Environmental Isotope Geochemistry, edited by Mark Baskaran, pp. 743-768. Springer, New York.

Smith, Erin, William Pestle, Alejandro Clarot, and Francisco Gallardo

2017 Modeling Breastfeeding and Weaning Practices (BWP) on the Coast of Northern Chile's Atacama Desert during the Formative Period. Journal of Island and Coastal Archaeology 12:558-571.

Stein, Mordechai, Abraham Starinsky, Amitai Katz, Steven Goldstein, Malcha Machlus, and Alexandra Schramm

1997 Strontium Isotopic, Chemical, and Sedimentological Evidence for the Evolution of Lake Lisan and the Dead Sea. Geochimica Cosmochimica Acta 61:39753992.

Stuiver, Minze, and Henry Polach

1977 Discussion: Reporting of ${ }^{14} \mathrm{C}$ Data. Radiocarbon 19:355-363.

Stuiver, Minze, Paula Reimer, and Ron Reimer

2020 CALIB 7.1 [WWW program]. http://calib.org/calib, accessed June 16, 2020.

Torres-Rouff, Christina

2008 The Influence of Tiwanaku on Life in the Chilean 
Atacama: Mortuary and Bodily Perspectives. American Anthropologist 110:325-337.

Torres-Rouff, Christina, and Kelly Knudson

2017 Integrating Identities: An Innovative Bioarchaeological and Biogeochemical Approach to Analyzing the Multiplicity of Identities in the Mortuary Record. Current Anthropology 58:381-409.

Torres-Rouff, Christina, Gonzalo Pimentel, and Mariana Ugarte

2012 ¿Quiénes viajaban? Investigando la muerte de viajeros prehispánicos en el Desierto de Atacama. Estudios Atacameños 43:167-186.

Ugalde, Paula, Virginia McRostie, Eugenia Gayo, Magdalena García, Claudio Latorre, and Calogero Santoro

2021 13,000 Years of Sociocultural Plant Use in the Atacama Desert of northern Chile. Vegetation History and Archaeobotany 30:213-230. DOI:10.1007/ s00334-020-00783-1.

Uribe, Mauricio

2006 Sobre cerámica, su origen y complejidad social en los Andes del Desierto de Atacama. In Esferas de interacción prehistóricas y fronteras nacionales modernas: Los Andes sur centrales, edited by Heather Lechtman, pp. 449-502. Instituto de Estudios Peruanos, Lima.

2009 El período Formativo de Tarapacá y su cerámica: Avances sobre complejidad social en la costa del norte grande de Chile (900 AC-800 DC). Estudios Atacameños 37:5-27.

Uribe, Mauricio, Carolina Agüero, Dánisa Catalán, María José Herrera, and Francisca Santana-Sagredo

2015 Nuevos fechados del sitio Tarapacá-40: Recientes análisis y reflexiones sobre un cementerio clave del período Formativo del norte de Chile y Andes Centro Sur (1110 a.C.-660 d.C). Nawpa Pacha 35:57-89.
Uribe, Mauricio, Dante Angelo, José Capriles, Victoria Castro, María Eugenia de Porras, Magdalena García, Eugenia Gayo et al.

2020 El Formativo en Tarapacá (3000-1000 aP): Arqueología, naturaleza y cultura en la Pampa del Tamarugal, Desierto de Atacama, norte de Chile. Latin American Antiquity 31:81-102.

Uribe, Mauricio, and Patricia Ayala

2004 La alfarería de Quillagua en el contexto Formativo del Norte Grande de Chile (1.000 a.C.- 500 d.C.). Chungara Vol. Especial:585-597.

Uribe, Mauricio, and Estefanía Vidal

2015 Pottery and Social Complexity in Tarapacá: Reviewing the Development of Ceramic Technology in the Atacama Desert. In Ceramic Analysis in the Andes, edited by Isabelle Druc, pp. 15-35. Deep University Press, Madison, Wisconsin.

Veizer, Ján

1989 Strontium Isotopes in Seawater through Time. Annual Review of Earth and Planetary Sciences 1:141-167.

Walker, Phillip, Rhonda Bathurst, Rebecca Richman, Thor Gjerdrum, and Valerie Andrushko

2009 The Causes of Porotic Hyperostosis and Cribra Orbitalia: A Reappraisal of the Iron-Deficiency-Anemia Hypothesis. American Journal of Physical Anthropology 139:109-125.

Wood, James, George Milner, Henry Harpending, and Kenneth Weiss

1992 The Osteological Paradox: Problems of Inferring Prehistoric Health from Skeletal Samples. Current Anthropology 33:343-370.

Submitted February 4, 2020; Revised June 27, 2020;

Accepted May 10, 2021 